\title{
Men and Women Registers: Cooperative Principles in The Great Gatsby Movie
}

\author{
Puspita Khairunisya $^{1 *}$ and Kumara Tungga Dewa ${ }^{2}$ \\ 1,2 Department of English Language Studies, Universitas Hasanuddin, Indonesia \\ *puspitakhairunisya@gmail.com
}

\begin{abstract}
This research aims to understand the way of men and women express their utterance as men and women register in The Great Gatsby Movie, to find out the difference of men and women register in The Great Gatsby Movie, to find out the reasons for a violation that the casts utter in The Great Gatsby movie. A qualitative method was used in this research. The data was collected using a note-taking technique by doing transcription of the conversation. The authors chose the data based on women and men register and violation of cooperative principles. The results of the research indicate three things. First, men and women have special ways to express their utterances. Second, men and women have differences in expressing their utterances. The differences can be from their temper, intonation, and use of words. Third, men and women have various reasons to violate cooperative principles in a conversation.
\end{abstract}

Key words: Cooperative principle, men, register, women

\section{Introduction}

Communication is an important thing in our life in which people can build a new relationship. In communication, there are at least two parties, speaker and hearer. The speaker must encode the message into the communication channel, and the hearer then decodes the message to understand its meaning and significance. Misunderstanding can occur at any stage of the communication process. Effective communication involves minimizing potential misunderstanding and overcoming any barriers to communication at each stage in the communication process. An effective communicator understands his audience, chooses an appropriate communication channel, hones their message to this channel and encodes the message to reduce misunderstanding by the hearer [1].

The expression of intention from speaker to hearer can be done either directly or indirectly. In pragmatics, the expression of intention in communication is well known as a conversational implicature. Conversational implicature explains how someone can explain something, more than he said. It means that the statement has more meanings than just simple words. The speaker must try to explain his intention relevantly and clearly according to the condition. Then, the hearer tries to answer relevantly and clearly too. In another word, there are some principles that must be obeyed so that the conversation can run well by the speaker and hearer. These principles are well known as cooperative principles.

People have different ways to express their intention in conversational implicature. In communication, men and women generally have different characteristics. Men and women use different languages. The use of these variations 
of languages might appear different to their expressions in communication [2]. Based on the phenomenon above, I am interested in doing research on men and women register in conversation. This research is different from others because, in common research in conversational implicature, the other researchers researched about violation of implicature in conversation and only pragmatic aspect. Meanwhile, I did research about different characteristics to explain intention based on sex in conversational implicature. It is the combination of pragmatic and sociolinguistic aspects which is rarely studied. In this research, the problem is to find out the common of men and women register in a conversation movie "The Great Gatsby" [3]. The authors try to analyze the conversations or utterances that are uttered by actors and actress. The utterances were classified into nine characteristics of men and women. Then, the utterances also were classified into violation of maxims based on Grice's cooperative principle

\section{Theoritical Reviews}

\section{Previous Study}

Some students found about the conversational implicature that the prior researchers had conducted before as references. They are Haslindah Syam (2006), Ary Azhari (2010), and Rakhmah Hamdani (2013).

First, Haslindah Syam in "The Use of Cooperative Principles in Conversation on Radio Program English Lecture", analyzed on analyzing the violating which occurred in the conversation and the speaker's reason of violating the cooperative principles. She took the object from a conversation on the radio program which is called "English Lecture". In this research, she found that the most maxim violated was the maxim of relevance with 32.43

Second, Ary Azhari in "The Analysis of Cooperative Principles and its Maxim on Oprah Winfrey Talk Show", focused on analyzing the violation maxim and the real meaning of the speaker who violated the maxim. Besides, he also limited the analysis on the relevance maxim of cooperation principles. The object of this study was taken from the Oprah Winfrey talk show[5].

Third, Rakhmah Hamdhani in "The Conversational Implicature in Indonesia Now Talk Show", discussed analyzing the cooperative principles generally, the reason of the speaker in floating maxim and the way of speakers in floating the maxim. The object of this study was taken from Indonesia Now talk show [6].

In this research, the authors have some different focuses to analyze. This research focused on analyzing how characters of the participants based on sex generally in the conversation. The objects of this research are taken from a movie which is titled The Great Gatsby.

\section{Pragmatics}

Pragmatics was proposed by Morris. Morris (Kushartani 2009: 27) told that he was interested in signs or semiotics. He divided semiotic into three branches of sciences; they are syntax, semantics and pragmatics. He concluded that signs had three relationships; they were signed with humans or a group of people, sign with an object reference, and sign with other signs. He explained that the branches were pragmatics as the study of sign relations with humans or a group of people, semantics was as a study of sign that relations with object reference and syntax were as a study of sign relations with other signs. They were called semiotics [7].

\section{Coporative Principle}

Grice (Cook 1990: 35) told us that there are four maxims in cooperative principle that must be followed by speaker and hearer[8]. The four maxims are as follows:

\section{Maxim of Quality (be true)}

Participants have to give true information based on reality. There are two sub maxims in the maxim of quality, as follows:

a. Participants do not say something wrong

b. Participants do not say that for which they lack evidence

In the maxim of quality, someone wishes that his partner contributes seriously. If someone asked you to buy a diary in the bookstore, does not give him a notebook. Although, it is almost the same they have different qualities.

\section{Maxim of Quality (Be Brief)}

In communication, participants give enough contribution. They do not give more information that has useless information in the conversation. Participants give contributions as informative as is required

a. Participants do not give contribution more informative than is required 
In the maxim of quantity, someone hopes that his partner gives enough contribution not more or less. If someone asked you to give him only one apple, he hopes that you will give him only one, not two or more.

\section{Maxim of relevance (be relevance)}

Participants have to speak relevantly based on the topic discussed in the maxim of relevance. In the maxim of relevance, someone needs the right contribution from his partner in every part of the interaction. For example, if you are part of a study group, your friends hope that you will work together with them in every interaction. They do not hope that you will give good facilities or cost, although they need those facilities and payment in the next part.

\section{Maxim of Manner (be clear)}

Maxim of manner is the way of participants telling information that will be told. This maxim has four sub maxims, as follows:

a. Participants have to avoid obscurity of expression

b. Participants have to avoid ambiguity

c. Participants have to give information clearly and briefly

d. Participants have to utter orderly the utterances.

Someone has to understand about his contribution that must be done and do it rationally.

\section{Violation of Cooperative Principle}

In reality, participants do not always obey cooperative principles. Sometimes, the maxims also are violated in the conversation. There are some examples showing flouting of the maxims:

\section{Violation of Quality Maxim}

Violation of quality maxim happens if the participant in a conversation answers something wrongly and they lack evidence.

\section{Violation of Quantity Maxim}

Violation of quantity maxim happens if the participant does not give a contribution as informative as is required or give contribution more informative than is required.

\section{Violation of Relevant Maxim}

Violation of relevant maxim happens if the participants say irrelevant information.

\section{Violation of Manner Maxim}

Violation of relevant manner happens if the participant has ambiguity and unclear answers.

\section{Women Register}

Women usually tend to use the standard language more than men do. Women use speech to develop and maintain relationships. Furthermore, they answer more polite than men. Lakoff (Holmes 1993: 80) she tells that there are several features for women's language as follows:

Women tend to use polite language and take special care to say please, thank you, and apologize during the conversation. Furthermore, women also use modal forms, modal auxiliary verbs such as could, may, might, should and would more often than men. Meanwhile, women avoid strong swear words and change to oh dear, my goodness and so on.

\section{Compliments}

According to Lakoff, women give compliments more often than men. Furthermore, women usually receive more compliments than men.

\section{Hedges}

According to Lakoff, women usually uses expressions like kinda, you know, well, sort of, and many more. Kinda, you know, well, sort of are called hedges. Hedges are used to revealing a speaker's uncertainty of an utterance.

\section{Question-tag}

In a conversation, women sometimes are uncertain with their utterances. They use question tags in their statements. On the other hand, they also rise their intonation when they give a statement. For example, "You are cute with your 
new dress, aren't you?" / "Oh, around eight o'clock?". Women tend to ask questions even when declarations are expected because, unlike men, women usually are insecure with her opinion.

\section{Intensifiers}

Intensifier is a word that has little meaning itself but is used to add force to another adjective, verb or adverb. Examples of intensifiers are adverbs such as extremely and strongly.

\section{Emphatic Stress}

It is almost the same with rising intonation in the conversation but emphatic stress tends to be used in a word in the utterance. Women usually emphasize one word in their utterances.

\section{Empty Adjectives}

Empty adjectives are adjectives that are used by people as expressions of admiration or approbation. Some empty adjectives are adorable, charming, cute, divine and lovely. Women usually use these empty adjectives in their conversations.

\section{Men Register}

Men have active characteristics and like an adventure. They also are aggressive and ambitious. They like to compete with others and be a leader because of their ambition. Another characteristic, they like to say something directly, are dominant, objective and have high confidence. They are not easy for offended and not emotional. They are assertive, adult, and direct, while women's language is immature, hyper-formal, or hyper polite and non - assertive. They usually use their logic to do something or say something. There are some characteristics of men register, as follows:

\section{Interruption}

Men usually interrupt someone during the conversation. It can happen when men want to speak something important or hold on to their true statements. Man tends to compete during the conversation.

\section{Insult}

It is different with women who avoid strong swear words, men tend to speak directly, simply and clearly. Men is easier to speak like what the hell or what the fuck than woman.

\section{Command}

Men tend to command directly. They will command with direct request and usually avoid politeness. On the other hand, women usually use indirect commands with politeness words.

\section{Resistance}

Men usually are resistant to his utterance. Men rare are uncertain with their utterance. They will say cannot if they cannot do something.

\section{General Knowledge/Topic of Men}

Men's topic usually discusses general knowledge or last news than celebrity news. They do not like discussing their life's rumours. It is opposite with women's topic. Women tend to gossip and talk about other people's life and their life themselves.

Men also do politeness, compliments, insecurity and some women's characteristics that it has told before, but they rarely do these actions. In this explanation, women tend to be nice participants with good actions in the conversation than men. Women are probably more conscious about using a better language because women generally are judged by how they speak. On other hand, men are more likely to get judged based on their actions.

\section{Methodology}

The authors used the qualitative research method. To elaborate the cooperative principles in The Great Gatsby movie, the authors need the data from the script. Furthermore, the script is analyzed descriptively to explain in detail phenomena based on the theory of cooperative principles [9]. The purpose of this method is to find more information, in the form of theoretical issues that may support the writing. That is why the authors find any reverence related to research from books, journals, and many more. The authors took the data from the video and script of the movie. Besides library research, the authors used field research to support the data collection process. The authors collect data by downloading the movie and its script. 
In this part, the authors used a descriptive qualitative method and a pragmatic approach. This study could be classified as a qualitative approach since the data were in form of words or sentences. The analyzing data was the process of systematically searching and arranging the data which have collected. The authors analyzed the data in accordance with the problems and the objectives of the study. The authors used several work procedures in analyzing the data[10]. Firstly, the authors downloaded the script and watched carefully the utterances in the movie. Secondly, the authors observed the appropriate data and identified the utterances that contained the cooperative principle. Thirdly, the authors classified the maxims of cooperative principles which were presented in the movie. The utterances with cooperative principles were grouped according to the kinds of maxims. Furthermore, the author described and elaborated the maxims of the utterances using the theory of cooperative principles. The data would be deeply analyzed using the descriptive qualitative method. The population of this research was taken from the script of The Great Gatsby movie.

\section{Findings and Discussion}

\section{Data Presentation and Analysis}

\section{Politeness}

Example I. Jordan and Gatsby speak a topic secretly. They don't want Nick to know it. Thus, Jordan apologizes to Nick that she cannot tell him. Gatsby is sorry to Nick because Gatsby keeps her from Nick. Gatsby and Jordan respect Nick, so they still act to be polite. It can be seen in those utterances: "Nick. I'm sorry, I swore I wouldn't tell" said Jordan, "Sorry to keep her from you, old sport". Said, Gatsby. Jordan and Gatsby consider Nick's feeling that they must talk to each other secretly without Nick. It must be awkward for Nick. Jordan and Gatsby say sorry to Nick, so he is not offended. Then, Nick thanks to Gatsby politely because he has been invited to his party. It can be seen in Nick's utterance: "Good night. Thank you".

Example II. Nick feels strange, and he wants to stand from his seat. He excuses to Jordan to go for a while. Yet, Jordan asks him to stay. Although, Nick does not like the situation, he still acts politely that he uses "please" at the end of his utterance. He says: "One moment, please". He does not want to offend Jordan about his feeling. Although Jordan knows his feeling about the awkward moment, Jordan begs to Nick for staying in his seat. Jordan uses "please" word for begging Nick politely. It can be seen in the Jordan's utterance : "Please, Nick, sit down. This is a polite restaurant". Thus, Jordan and Nick use "please" in their utterance as politeness act in order to not offend each other.

Example III. Nick offers some tea to his guests, Daisy and Gatsby. They say thank to Nick for the tea. They say thank to Nick as politeness act.

Example IV. Gatsby asks Nick to accompany Daisy because Gatsby has a business for a while. Gatsby asks Nick with politeness act. Gatsby's politeness act is indicated in the phrase "Excuse me" and the question "would you mind?".

In this movie, there are nine data about politeness. Based on this analysis, the men do politeness act more than women do. Politeness act tends to be used by women according to Lakoff, "To a greater extent than men, women use a polite language and special care to say please, thank you and to apologize during conversation" Lakoff [11]. It is not only women like using politeness act but men also like doing it.

\section{Avoidance of strong swear words.}

Example I. Daisy is supprissed about the decoration that is made to great her. The surprising can be seen in her utterance: "Oh! Oh, my goodness. I... I can't believe it. You.... Did you ransack a greenhouse?..... He is in love with me". Daisy uses strong swearing word to express her surprising.

Example II. Gatsby is nervous while meeting Daisy because they don't meet each other for long time. Gatsby uses avoiding a swear word with "Oh God" in his utterance. It can be seen in his utterance: "God! This is mistake, a terrible, terrible mistake"

In this movie, there are two scenes about avoiding strong words. They are used by men and women. It is not the same with Lakoff's statement who argues that women tend to use avoiding strong words than men. Men are easy to speak with strong words like "shit", "fuck" and so on but women change to other words like "oh", "dear" and so on. According to Lakoff (1975:24) "women avoid swear words, use hypercorrect grammar and super polite forms". The result shows that not only men also avoid strong words.

\section{Compliments}

Example I. Nick compliments Daisy as a greeting in their meeting. He tries to tell Daisy that her family in Chicago is longing for her. Nick explains it by compliments. It can be seen in these utterances: "Daisy Buchanan. The golden 
girl. A breathless warmth flowed from her. A promise that there was no one else in the world she so wanted to see," "Oh yes. About a dozen people send their love," "Daisy Buchanan, we can't live without you!".

Example II. Daisy compliments his cousin, Nick while having dinner together. Daisy is happy because Nick can come to her house. Daisy compliment can be seen in her utterance: "I just love seeing you at my table Nicky. You remind me of a rose, an absolute rose..".

According to Lakoff (1975), women give compliments much more often than men do. Further, women tend to receive compliments than men. It can be proved in this movie when Daisy gives and receives compliments more often than other actors in this movie.

\section{Insecurity}

Example I. Daisy feels insecure with her words so that she uses a question tag in her utterance "You remind me of a rose, an absolute rose... Doesn't he?". She is unsure about her words.

Example II. Tom drives his car to Wilson's workshop. Wilson sees him and recalls Tom's promise of selling his car to Wilson someday. Wilson remembers to him, but Tom's response is not accurate. Then, Wilson tries to comment "works pretty slow, don't he?" He thinks that the worker of Wilson works pretty slow, but he is unsure with his comment so that he uses a question tag.

Example III. Gatsby is unconfident about his preparation to greet Daisy. He utters three insecurity utterances "I think they did a fine job, don't you?," "You think it's too much?" "I think so too... She'll be impressed, won't she old sport?". In fact, the preparation is beautiful and almost perfect based on Nick's opinion "Beautiful."

According to Lakoff (1975:90), "women's language, rather than men's, as insecure and a lack of confidence". In these data, it can be seen that men are insecure more often than women are in this movie. Their insecurities have different meanings. Men tend to be insecure because they want to ensure their listeners but, women tend to be insecure because they are lack confidence about their utterances.

\section{Emphatic stress and Rising Intonation}

Example I. Jordan accepts shocking news from Gatsby, and she tries to tell Nick. She is enthusiastic to tell Nick with some rising intonation in her declaration. It can be seen in Jordan's utterance: "Nick! Nick! I've just heard the most SHOCKING thing; it all makes sense," "Simply AMAZING! It all makes sense. It all makes sense..."

Example II. Jordan and Nick arrange a meeting for Daisy and Gatsby. To answer Nick's question, Jordan says that Daisy does not know their plan. The utterance is "She's ABSOLUTELY not to know." Jordan tries to convince Nick that Daisy doesn't know about the plan. The rising intonation is a sign that Jordan's opinion is true, and she is really sure about her opinion.

Example III. Daisy is so surprised about Gatsby's house. She expresses with rising intonation as an amazing feeling. She expresses her rising intonation twice in this conversation. The utterances are "Oh, Jay...?! It's so grand!" and "I love it...!".

In this movie, there are four data about emphatic stress and rising intonation. There is only one man who expresses emphatic stress and rising intonation in this movie. The result is the same as Lakoff's statement. According to Lakoff (1975:191), "woman makes liberal to use emphatic stress and rising intonation". It can be concluded that women more often express emphatic stress and rising intonation than men.

\section{Empty adjectives}

Example I. Daisy expresses her opinion about the clock. Actually, it has no big meaning. It is just an etiquette act. It can be seen in her utterance: "Lovely though. A lovely .... Clock".

Example II. Daisy sees a beautiful piano in Gatsby's house. She reflects to say how beautiful is. Women usually reflect to say or to compliment when she sees beautiful things. It can be seen in Daisy's utterance: "Oh! It's beautiful!

In this movie, there are three data that express empty adjectives. There is no man expressing an empty adjective. According to Lakoff (1975:79-80), "women use empty adjectives like adorable, charming, and sweet, which express emotions rather than intellectual evaluation." The statement of Lakoff can be proved in this movie. All the participants of the empty adjective are women in this movie. 


\section{Interruptions}

Example I. Nick feels uncomfortable because he is sorry for his cousin, Daisy. He doesn't like the situation that Daisy doesn't know about her husband's bad activity. Nick tries to explain that he will leave because of his uncomfortable, but Tom interrupts him and ensures that the situation is normal as usual. It can be seen tom's utterances: "Nonsense....".

Example II. Tom wonders about Gatsby's life. Tom investigates Gatsby's life. Meanwhile, Daisy is uncomfortable with Tom actions. Daisy interrupts twice in this scene. Daisy hopes her interruption can stop Tom to investigate Gatsby's life. Daisy's utterances are "Tom!!!" and "I'll make you a drink Tom, then you won't seem so stupid to yourself".

Example III. Nick tries to convey to Gatsby about responsibility for Martyle's death. Gatsby interrupts Nick and denies the topic because Gatsby thinks that the important thing at that time is only Daisy's call. Gatsby is waiting for Daisy's call. He does not care about anything so Gatsby is deny Nick's comment. Gatsby interrupts 3 times in this conversation. The utterances are 'Daisy's going to call in the morning. Then we'll make plans, to go away together, 'She just needs time to think... She'll call. In the morning, she just needs time to think.' and 'She just needs to think. She's going to call in the morning.' Gatsby continues interrupting three times because he does not care about Gatsby's statement.

There are three data that express interruption. Two men interrupt five times and a woman interrupts twice. It can be concluded that men tend to interrupt more often than women in this movie. It is the same as Lakoff's statement. According to Lakoff (1975:115-116), "Men interrupt others and women in particular far more often than women do." The statement of Lakoff can be proved in this movie.

\section{Insults}

Example I. Nick to Gatsby: You're acting like a little boy! You're rude. Daisy's in there all alone and... Nick insults Gatsby because Gatsby just closes his mouth without speaking anything to Daisy.

Example II. Nick to Gatsby: Tom was right! You're nothing but a goddamn coward! Nick insults Gatsby directly. Nick agrees with Tom that Tom thinks Gatsby is a goddamn coward.

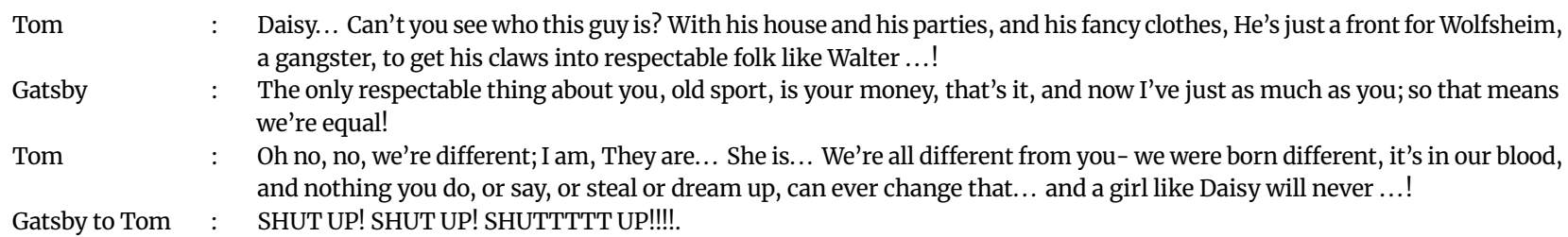

Example III. Tom insults Gatsby that Gatsby has different blood from others. Tom thinks that Gatsby will never change to be a better person because he is from a poor family and never be changed. It can be seen in Tom's utterance " Oh no, no, we're different; I am, They are... She is... We're all different from you- we were born different, it's in our blood, and nothing you do, or say, or steal or dream up, can ever change that... and a girl like Daisy will never ... !"

There are four data that express insult in this movie. All of the participants who insult in this movie are men. Talbot also says that men tend to insult more often than women. According to Talbot "which reveal that men generally tend to insult each other more than women". Talbot's statement can be proved in this movie. It can be concluded that men tend to insult their listeners while in the conversation process [12].

\section{Commands}

Example I. Tom commands Myrtle not to speak Daisy's name directly. The utterance is "You've got no right to speak her name".

Example II. Suddenly, Nick leaves his house, so that Gatsby and Daisy can talk freely. Meanwhile, Gatsby commands that he will speak in order Nick cannot leave them and Gatsby will be not nervous in front of Daisy. Yet, Nick realizes that Gatsby and Daisy are embarrassed by each other, so they need to talk freely without Nick. Then, Gatsby commands Nick not to talk loudly while Nick explains that Gatsby and Daisy are both embarrassed by each other. It can be seen in Gatsby's utterances: "I've got to speak to you!" and "Don't talk too much!". Gatsby commands because he feels unstable if the situation runs well without Nick.

Example III. In this scene, there are five commands. The commands are from Daisy and Her mother. It happens because they are mad at each other. Daisy is frustrated because she has already received the letter from Gatsby in the morning. Suddenly, Daisy wants to cancel her wedding in the afternoon. Daisy is mad and commands Jordan to tell Daisy's family that she does not want to marry Tom. It can be seen in Daisy's utterance: “Tell them Daisy's 
changed her mind!," "Give them back!". Meanwhile, Daisy's mother holds Jordan not to follow Daisy's command. Then, Daisy is still mad and she commands that she wants everybody to leave her alone. It can be seen in Daisy's utterance: "Leave me alone". Next, Daisy's mother commands Jordan to run the bath in order for Daisy's mother can feel fresh and get her good mood back. The utterance is "Jordan, run the bath! now!". In this situation, Daisy commands out of control. She does not think about all the preparation for the wedding, and her mother is shocked by her command.

There are six data that express command in this movie. There are four expressions of command from men and four expressions of command from women. Women and men express command equally often. It is not the same as Talbot's statement. According to Talbot (1998:87-90) "Men tend to give orders to a greater extent than women". Although men and women like to command, they have different expressions to command their listeners. Women are more polite than men while commanding to their listeners. Women tend to add "please" or politeness words in their commands. Meanwhile, men command directly without adding politeness words. It can be concluded that men and women like to command equally in this movie.

\section{Resistance}

Example I. Tom wants to introduce Myrtle's sister to Nick, but Nick disagrees about this idea. Nick resists two times as disagreement, but Tom forces Nick to accept his request. Nick's resistance: "Oh no, that's alright, I'm busy", "Really, I can't"

There is only one man who resists in this movie. According to Talbot (1998:97), "all-male conversations, rather than all-female, display aggression, competition, arguments and opposition". The statement of Talbot can be proved in this movie. The result is men that tend to resist his listener.

\section{Discuss factual news}

Example 1. Daisy and Jordan talk about Nick's rumour. Suddenly, Tom changes the topic to civilization. Then, Daisy and Jordan feel bored about civilization topic, but Nick tries to respond to the rumour. Daisy and Jordan prefer gossip to the factual topic. It can be seen in Daisy's utterance: " Nicky... I heard a rumour, that you were getting married to a girl out west". On the other hand, Nick tries to change the topic. Nick's utterance: "Can't we talk about something else? Anything? Crops? You're making me feel uncivilized, Daisy". Then, Tom agreed with Nick and said: "Civilization's going to piece Have you read 'The Rise of the Colored Empires' by this fellow Goddard?. It proves that Nick and Tom prefer factual topics to gossip themes.

Example II. Nick and Gatsby enter a cramped shop. Gatsby introduces his friends one by one to Nick. One of them, Wolfsheim talks to Nick about a business. It can be seen in his utterance 'So... How is the bond business, $\mathrm{Mr}$ Carraway?' , 'I understand you're looking for business negotiation'. It can be concluded, Man meets a man tending to talk about general knowledge or happening issue about the improvement something.

There are two data that express factual news. Two different men tend to like to discuss factual news with their listeners than gossip about other people's life. According to Tannen, "men's tendency to discuss factual news, news like bulletin" [13], [14]. The statement can be proved in this movie. The result is that men are more like to discuss factual news than gossip about other people's life.

\section{Violation (Men)}

Example I. It is a violation of quantity maxim. Nick violates his answer to Daisy. He gives more information than is required. Daisy just asks Nick if her family misses her or not. Nick should answer Daisy's questions such as 'Oh yes, they do', or 'yes, they miss you.' Actually, Nick does not has to intend to violate the cooperative principle but he tries to tell Daisy that her family misses her so much.

Example II. Tom invited Nick to a small party in an apartment. There is Myrtle and her friends. Nick feels confused and uncomfortable because he must attend a party with Tom without telling Daisy before. Nick asks Tom what they are doing exactly in there. Tom can see Nick's uncomfortableness. Then, Tom answers Nick's question with an unsuitable answer. Actually, Tom conveys to Nick that Nick must trust Tom about the happening will be alright for Daisy. In the fact, Tom has affair with Myrtle that night. So, Nick feels guilty Daisy for this situation. Tom's answer is 'Trust me' but the question is 'What are we doing?'. It is an unsuitable answer. It is called a violation of relevance because the answer is not relevant to the question. Tom should answer such as 'We are parting now.' It can be seen that Tom violates the cooperative principles because Tom thinks that the question of Nick is not important because Nick can see what happened in that place. Otherwise, Tom just conveys to Nick that everything is alright and just trusts Tom. Example III

It is a violation of manner because Nick answers unclearly and not briefly. Catherine asks Nick twice and Nick answers twice too with violation of manner. Catherine asks 'Do he live on Long Island, too?'. Nick does not answer yes or no, he just says 'I live at West Egg'. Then, Catherine asks Nick 'do he know Gatsby?'. Nick just answers "I live right next door to him." It is ambiguous because someone who lives next door with someone else is no guarantee 
that he knows well about his neighbour. Nick should say for the first question is 'no, I live at west egg' or 'yes, I live on the long island'. For the second question, he should say 'yes, I know him' or 'no, I do not know him'.

Example IV. Nick asks Gatsby about 'what's she got to do with it?'. Gatsby does not relevantly answer the question. Gatsby just convinces that Jordan has never done anything wrong but he does not explain what Jordan has done. It is a violation of the manner maxim because Gatsby cannot answer clearly about Nick's question. It can be seen that Gatsby actually hides something about Jordan to Nick.

Example V. Gatsby does not answer the question unclearly. At the end of the conversation, Gatsby also ignores the topic of their conversation. Gatsby tries to change the topic. It can be seen in his end utterance 'Now, old sport, about Miss Baker, and that request we spoke of...' It can be concluded that Gatsby might do not know well about the man's case that Nick asks, or Gatsby thinks that the question of Nick is not important. It is more important to talk about Jordan.

There are several reasons why men violate in this movie. They violate the maxim of quality twice, the maxim of relevance once, the maxim of manner six times, the maxim of quantity three times. They violate the maxim of quality because they are unsure of their statement and want to hide something from their listener. They violate the maxim of relevance because they want to change a topic indirectly. They violate the maxim of manner because they want to their listener get meaning of their utterances indirectly. They violate the maxim of quantity because they want to give more information in order for their listener to get satisfied with their answers.

\section{Violation (Women)}

Example I. Tom gets a telephone from someone else. Suddenly, Nick asks Jordan 'Is something happening?'. Jordan answers 'I thought everybody knew'. Jordan thinks that she does not need to explain to Nick because everybody has known but the answer is not relevant with the question based on cooperative principle. Jordan should just explain what the real happening is without making Nick wonders about the telephone.

Example II. It is a violation of the relevance maxim. Myrtle's answer is not relevant to the question. She should answer 'yes' or 'no.' But, she just insults tom that he's a greasy little scumbag. Although the expression of Myrtle shows that she definitely does not like Tom because of his action, the answer is not suitable.

\section{Example III.}

Nick : And you think I should? I mean, does Daisy want to see Gatsby?

Jordan : She's absolutely not to know. You are just supposed to invite her over so he can "happen to drop by."

It is a violation of the relevance maxim. Jordan's answer is unconnected with the question. It might be that Jordan is unsure whether Daisy wants to see Gatsby or not. So, she thinks that it will be answered clearly when Daisy and Gatsby meet unconditionally.

Example IV. In this conversation, Daisy does violation of maxims twice. Gatsby is shocked by the expression of Daisy. Gatsby asks 'What is it?' Daisy answers 'It's just ... It makes me sad, because...' It is a violation of the manner maxim. Daisy answers unclearly. Daisy is doubt about herself that she feels sad because she sees such beautiful things. Next, Gatsby asks 'why', Daisy answers 'because.... It's just because I've never seen such beautiful shirts before.' It is a violation of the quantity maxim. Daisy should just answer because I've never seen such beautiful shirts before' without add some words such as 'because' twice and 'it's just'. She should no doubt say that she is sad because she has never seen such beautiful shirts before.

Example V. It is a violation of the quality maxim because Daisy lies to Tom. Tom asks 'Where were you?' Daisy answers 'With Nicky. Mr Gatsby was showing us the grounds.' In the fact, Daisy spends her time only with Gatsby. But, Nick tells Gatsby that Tom is looking for Daisy. Then, Daisy goes to Tom with Nick. Daisy does like that because she does not want Tom mad at her knowing her wife speaks secretly with another man.

\section{Conclusion}

There are several dominant registers of men and women in this movie. Men tend to insult, command, be insecure, be resistant, interrupt, and talk about a factual topic. In fact, in this movie, men are dominant do polite acts with their opposite speaking. Actors have more scenes than women is one of the cases in politeness. So, the theory about politeness, it is irrelevant in this movie about women doing more polite acts than men. Then, insecurity tends to be used by women, is that irrelevant in this movie. Men are more insecure than women. Next, Men also like to 
compliment their listeners. Women tend to avoid strong swear words, use emphatic stress, rise intonation, and use empty adjectives. Women also like to compliment and receive compliments from their opposite speaking.

Men differ from women in appearing their temper. If men are angry, they tend to insult their opposite speaking. On the other hand, women use a swear-strong word or change the topic. In insecurity, men use question tags to ensure their utterances to their listeners but women usually use question tags because they are not confident about their utterances. In interruption, men tend to interrupt because they persuade their listeners for following them. Otherwise, women usually interrupt to show their dislike about utterances of their opposite speaking and they do not force much for following them. In command, men tend to use their temper and force their listeners to follow their command but women command their listeners by begging and adding some politeness word such as, please.

There are several reasons actresses and actors in this movie violate maxims. They violate the maxim of quality because they feel unsure of their answer and want to hide something from their listener. They violate maxim quantity because they want to give more information in order for their listener to get satisfying information. They violate the maxim of relevance because they want to skip a topic and want to change a topic conversation indirectly. They violate the maxim of manner because they want the listener to get the meaning of their utterance indirectly.

The writer suggests for other researchers who want to study linguistic aspects through several media such as drama, novels, talk shows, movies, and so on, should understand theory clearly and know to analyze all from linguistics aspect, especially in women and men register and cooperative principle. It is better if the researchers study more and have some references from related books or journals. The other researchers who want to analyze men and women register can compare men and women register through two media or two different background cultures. Besides, the other researchers can compare differences of violations of maxim based on different media or different background cultures.

\section{References}

[1] R. Wardhaugh, An Introduction to Sociolinguistics, Oxford: Blackwell Publishing, 2006.

[2] Abdul, Leonie and Agustina, Sosiolinguistik Perkenalan Awal, Jakarta: Rineka Cipta, 2010.

[3] Baz Luhrmann, "Script of The Great Gatsby". Warner Bros. Pictures [online]. Available: https ://www. scripts . com/script/the_great_gatsby_589

[4] H. Syam, "The Use of Cooperative Principles in Conversation on Radio Program English Lecture," Undergrduate thesis, English Dept, Universitas Hasanuddin, 2006.

[5] A. Azhari, "The Analysis of Cooperative Principles and Its Maxim on Oprah Winfrey Talk Show," Undergrduate thesis, English Dept, Universitas Hasanuddin, 2010.

[6] R. Hamdani, "The Conversational Implicature in Indonesia Now Talk Show," Undergrduate thesis, English Dept, Universitas Hasanuddin, 2013.

[7] Kushartani, et. al., "Pesona Bahasa Langkah Awal Memahami Linguistik," Jakarta: PT Gramedia, 2009.

[8] G. Cook, Discourse. Oxford: Oxford University Press. 1990.

[9] Mahsun, Metode Penelitian Bahasa: Tahapan, Strategi, Metode dan Tekniknya, Jakarta: Rajawali Pers, 2011.

[10] Sugiyono, Metode Penelitian Kuantitatif Kualitatif dan R\&D, Bandung: Alfabeta, 2012.

[11] R. Lakoff, (1973, April) "Language and Women's". Language in Society [online]. Vol 2, No.1 pp 45-80. Available: https://doi.org/10.1017/S0047404500000051

[12] M. M. Talbot, Language and Gender: An Introduction, Cambridge: Polity Press, 1998.

[13] D. Tannen, You Just Don't Understand: Women and Men in Conversation, New York: William Morrow, 1990.

[14] D. Tannen, Gender and Discourse, New York: Oxford University Press, 1994. 